\title{
Macdara Woods
}

\section{Notes Toward Paros. Home/Lands}

I am sitting here in the park across the way from where I live, in Dublin. The park is one hectare in dimension, with trees, a little lake, an island: there are ducks, moorhens, swans, pigeons, this city's everpresent sea-gulls, and for some years a single splendid heron lived in the largest trees, surviving on the carp in the lake and whatever else it might forage. The park is known as The Ranelagh Gardens, called after the eighteenth century pleasure gardens of that name that occupied the space, a five hectare site developed by Lord Ranelagh, from Wicklow, who had similar pleasure gardens in London, on the site of the present Chelsea Flower Show.

There is something right in thinking about this essay in this location because city parks are reminders of our essential transience. Richard Crosbie made the first manned balloon ascent in Ireland from here, on the 19th January 1785, setting off in the direction of Wales, on the other side of the Irish Sea, and coming to earth less than ten miles away as the balloon flies, in Sutton, on the other side of Dublin Bay.

Some three years later a community of Carmelite nuns moved here, in 1788, to Willbrook House, at one time part of the pleasure gardens, and also home to the Protestant Bishop of Derry, Dr William Barnard, and here they stayed until 1975 when they concluded a very profitable deal with a building speculator, and moved to Malahide: repeating overland the itinerary taken by Crosbie a hundred and ninety years before.

There used to be a wicket gate, through which they sold shrouds, in the railway bridge exit to the grounds, set in an arch incised with Masonic arcana. The same railway, shut down in the fifties but now reopened for a light tram system, constituted the Harcourt Line to Bray for the first part of the last century, travelling through Foxrock, and through the plays of Samuel Beckett who lived there.

In the 13th century a large section of the citizenry of Dublin, English colonists from Bristol, was masssacred here by the Irish O'Tooles and O'Byrnes, in the course of their annual civic celebration on the banks of the now underground river Swan.

Layerings. All things fall to the bottom of the sea.

And somewhere there are the figures of myself and my son in the early 1980s, as I wheel him in his buggy around the still unreconstructed paths.

But I am not from here. Nor is he.

About a half a mile away, in Leeson Street, is the house where I was born, number 12. By chance, as a random result of the subsequent positioning of bus stops, if I take the blue Aircoach from the airport when returning from a journy abroad it drops me off at the house in which I was born. A house which for some years now appears to be unoccupied. 
I am not from there either. Nor indeed from any of the surrounding neighbourhoods, the Grand Canal, Lower Leeson Street, Pembroke Street, FitzWilliam Square, Stephen's Green, although my internal urban childhood map, from the earliest moment on, is composed of precisely this area. So much so that I seem to know it indelibly, how I can't say, from before I was born. What is it I am remembering?

Where from? My father once told me I had been conceived in a field in Co Meath, on my maternal grandmother's farm. Near running water, beside furze covered hills, and it must have been in June, with the whole countryside lush and in riot. But he was a fabulist, and so I don't know.

But I do know that I have a genuine physically accessible lost garden of childhood, a personal Tigris and Euphrates of my own, in the wide hemispherical sky of Co Meath and the long seemingly-endless summer evenings, light up to eleven, and at night the corncrakes in the half-dark, a lost garden that has made it difficult for me to live in large cities. When I was young the population of Dublin was in the region of 650,000 , today it is heading toward a million and a half.

Dublin is growing, and it takes longer and longer, in time and distance, to get back to the countryside of open sky, twisting green lanes of roads, that whole ambience of creationin-waiting that I remember from childhood. It is still there somewhere, I like to think, and sometimes I believe again - even if only for an instant - that I have found it, but there is always that irredeemable gap between memory and recollection, between reliving something and reinventing it. For someone like me, born and raised near the sea, it is like seeing a huge expanse of inland water - in Toronto, or Chicago, for example - and not smelling the sharp bite of salt.

And yet, as with the shadowy figures of myself and Niall walking round in the park in the '80s, I am still there with my Uncle James in a beat-up old Ford van in the 1940s, travelling the roads of Meath, Westmeath and Longford, ostensibly in search of cattle for him to buy, but also following his great passion, greyhounds. There were no radios in cars or vans in those days and our entertainment while we drove along was in singing songs, reciting poems and ballads, and in the stories James could tell me about all the places, villages and townlands, that we passed through. The histories of which families had lived in which houses and the stories and accounts of their lives from generation to generation. How houses and land had changed hands, of people who had been famous in local history - the man who was so obese that he had to be larded every couple of years, people who had drunk their farms away, the ruined house of a member of the gentry class who amused himself and his guests by shooting eggs off the serving-boy's head. People who had changed religion or made pacts with the devil, the man who sent his new bride back to her family when he discovered she couldn't read the time of day, famine stories, stories of revenants, scandals, and an ancestor of my own, who actually succeded in taking his money with him rather than leave it to his relatives by the simple expedient of eating the bank notes.

And this was the exercise of dinnseanchas, a Gaelic word which may be translated as topography, but is really the soul of place. The topography and history, the people who had lived there and their story, the songs and histories, both recent and ancient: each bush and river and small hill and plain in rural Ireland too has its dinnseanchas, and he was passing his knowledge of his context on to me. 
Bequeathing, in a sense. The connection of belongings and belonging. I do not speak of amassing great wealth, corporate or private, but of the ritualistic and very functional power of symbols - such as, say, the pots carried by nomadic peoples, or how North African women can carry the cash wealth of their family group in the form of gold and jewellery. Or how rural Irish women up to the 50s and 60s controlled the cash-flow products of the farm: the butter, chickens, eggs, Christmas turkeys, pig, and of the power that goes with this.

My mother's people, the McConnells, arrived on the land in Meath in the person of a young man from Cavan who came to the local town with a load of eels to sell after the Famine. The farm was held at that time by a Miss Sheridan, an unmarried woman in her thirties, and it was assumed by her relatives that she would remain such and that the property would come to them.

However, she saw the young man on the eels as he passed along the road by her top-field and she was greatly taken, so much so that she contrived to be in the same place when he passed by on his way back to Cavan. She invited him in for refreshment, and he never left. A short later time the local priest had them married to offset the scandal.

For what did we ever claim to be/In all our caravanserei, but...

people of the high fields

travellers of the wandering rocks

with tongs and cauldron?

Who did we ever claim to be

but the stories we carry with us -

half of the cake with my blessing

or the whole of the cake with my curse

My mother left that house as a very young woman, but she went back consistently throughout her life. After her mother died and the customary family rows began, she tried to keep the land together. When she was already an old woman she and my sister made an illicict foray and seized some things from the house, oil lamps and photographs, and - most significant of all - a large iron cooking pot, stamped with the name Sheridan and the date, which had been cast to make stirabout to feed the hungry people from the local town during the Famine.

The Famine pot from Meath, a symbol of dispossession, ended up in the garden of my mother's suburban house in Dublin. Where it still is. Arguably, in that improbable context, a stronger symbol than ever, even to the point of possibly - and very wrongly being misconstrued in the new Ireland as Disneyland folksy, a piece of kitsch.

To a greater or lesser degree dispossesion is our common human lot, something rediscovered by each generation. We are dispossessed by time itself: as by political decisions over which we have no control, in which we have no say. Dispossessed by death, by family members, by our fears, by chicanery and scam artists, by the media, by government spokespersons, by the next generation, and by journalistic doctors of spin.

To be a Citizen of the World in the Thomas Paine sense is not, I feel, the same thing as living in a Global Village. And living in a Global Village will not remove the facts of emigration, exile and dispossession, loneliness and alienation. But, as Kavery Nambisan 
quietly and shockingly reminded us one morning during the conference in Paros, a person can live quite adequately in a cement pipe, some of the people living and sleeping in the streets in India get up each morning and go off to their job in the bank. We have to define what we mean by homelessness as much as we have to define what we mean by home. In the case of my own country we have had a shift of demographics and economic circumstances in the last twenty years or less which means that for the first time ever in our history we have had immigration instead of emigration; people coming to the country from outside as opposed to Irish people leaving. And coming in large numbers: at present one person in ten living and working in Ireland was not born there. We have always had an awareness of the outside world in that there isn't a single family that doesn't have at least one member living abroad; the fact of our Diaspora is part of our mind set and always has been, in song, story, politics, literature, education, identity, self-image. It is not so much that the world has now come to us, or that the descendents of those who left have come back, although both propositions are true, as that our way of recognising ourselves is in the process of being stood upon its head. And with some wonderful manifestations: the folk-tale minarets of the new custom-built Mosque in the upmarket Dublin suburb of Clonskeagh, or the occasion in 2005 when I went into a school in Longford and saw notices of good wishes for the school Gaelic-football team written up in Cyrillic script.

All of which is welcome: surprisingly frequently things can be best explained by contradictions and it is how we have traditionally done it. Maria Edgeworth, an Irish woman born in Oxfordshire in 1767, has written joyfully of the imaginative agility and validity of the Irish Bull as a linguistic, communicative device. We have a long developed ironic process of psychological macaronics to go with the literal macaronics of alternating conflicting lines of verse, straddling two languages, two cultures, saying two contradictory things at the same time and in the same context, like the prehistoric Janus headed stone figures facing both ways on Boa Island in Lough Erne in County Fermanagh. It is a mere accident of history that I am writing this in English: the other language speaks. There is indeed no word for Yes, in Gaelic, nor yet for No. The syntactical mind-set is: It is not true that it is, or it is true that it is not.

After my mother died the ritual of family break-up continued into my own generation to the extent that I possess no tangible symbols from my childhood, as say photographs of my mother and father - I sometimes almost wonder should I and my son now make a foray out to the unfriendly and uncommunicating suburbs to liberate oil lamps and the famine-pot in our turn? Or, indeed, would anyone of his generation be bothered? Just as Irish Civil War politics came to an end with my contemporaries the traditional relationship of inherited belongings and belonging has changed utterly in my lifetime. In a way for someone of my time and disposition it seems almost inevitable that I should be so dispossessed, almost a psychological relief, because my parents, and many like them, were themselves essentially and idealistically dispossessed throughout their lives.

They were born into the British Empire, in 1912 and 1911, were Irish Republicans, Gaelic and English speaking by choice and inclination, found themselves living after 1922 in the Irish Free State, then after 1948 in the Republic of Ireland, but this was not the Republic they had envisaged, a 32 County Republic, in the tradition of the eighteenth century revolutionary Theobald Wolfe Tone: "To unite the whole people of Ireland, to abolish the memory of all past dissentions, and to substitute the common name of Irishman, in the place of the denominations of Protestant, Catholic, and Dissenter--these were my means." 
An unexceptionable statement of intent, but one which meant that at no stage in their politically conscious lives did they find themselves included in a State the validity of which they could fully accept. In a kind of psychological exile, but powerless to change it; a de facto impasse, without retreat. Unless into disengaged alienation, or subversion, or total withdrawal from reality. Or, as for some, all three together.

One day in the eighties I drove over the Border into the Northern part of this island, which is free passage as it is also between this island and the neighbouring one. Some twenty miles further on a personnel carrier passed me by, saw the southern registration number, pulled in in front of me causing me to pull up. A complement of flak-jacketed policemen armed with automatic weapons jumped out, surrounded my car, asked me to step out, open the boot - which they searched, asked me to identify myself, which I did, and when they had satisfied themselves that I was no present threat and I was back once more in my car, one poked his gun through the window at my head and asked if I had my motor insurance. I pointed to the certificate on the windscreen, but no, he said, did I not have my actual insurance document? No, said I, but I can produce it later.

And then we came to the central nub of the matter, the weasel filioque clause as it were.

Don't you know, said he triumphantly, that you have to have your insurance with you when you drive your car in a foreign Country?

No, say I.

Because there is no way that I can say that the six counties of Derry, Antrim, Fermanagh, Tyrone, Armagh and Down constitute a Foreign Country. And we have this in common - he knows it and I know that he does. There is a collusive madness to this engagement, as there is to the policeman's question and why he asked it in the first place. The wilful unreason of Lear and Cordelia caught knowingly in semantics. We are aware of how we have come to be there, aware of what impels us into our positions, and as is so for all actors who have studied their script our freedom of choice is the freedom of confrontation. Two individuals on a stretch of road. No need, even, of an audience. Later, on the inside door of a toilet cubicle in a hotel I find: Fenian Bastards Go Home.

History, says Stephen Dedalus, is a nightmare from which I am trying to awake. But what to make of a fisherman's hut in Goa, full to overflowing with Goans watching Baywatch? What to make of a talking-head CNN broadcast I caught in a hotel room in Moscow in April 2003 when the US Army was driving across Iraq: The only question really is how much, how thoroughly we should shake up the Middle East now that we're there? Or another CNN programme I saw in a hotel room in Perugia, an ex-CIA operative speaking about the Agency's part in the overthrow of Allende's Government: The truth is, he said, the destabilization of Chile was comparatively easy to achieve.

Across the world tens of millions of people marched to prevent the human catastrophe that Iraq has become, did it make any difference? History is the movement of peoples and time the moving measure of change. I think it was Trevor Roper who declared that in the end there is no such thing as the opinion of history, only the opinions of historians. 
And what to do when one's own country is the most foreign of all, terrible in its familiarity? That is no country for old men: indeed, nor for young ones neither I thought when I was young with the orthodoxies of the late 1950s entrenched around me. My own solution at the age of sixteen was to leave, and for all that I have remained formally based in Dublin I have been on the move since. I would rather be genuinely foreign on the Corso Vannucci in Perugia, or the Ramblas in Barcelona, or on the Avenue of the Americas in New York than feeling so in Dublin, because the truth is I can recognise the foreign country in a way that I have not been able to accept my own. Nor it me.

The Irish poet John Montague, speaking of our dead colleague Michael Hartnett, once said to me that whereas it is not necessary to be a learned person to be a poet, all poets are of necessity learned people. A corollary being that learning, in the end, leads to simplicity.

I am thinking of an apercu of another Irish poet, Patrick Kavanagh, achieved near the end of a troubled and troublesome life: There are two kinds of simplicity, he said, the simplicity of going away and the simplicity of return. In conversation in Paros I found mayself saying that I felt I had lost the village as it were, and wondering how this had come about - had I somehow not been careful enough? Somehow transgressed. Not been sufficiently cognizant of the proprieties of place, the filial observances.

Exile, whether voluntary or involuntary, internal or external, is after all much less a form of dispossession than a replayed-out version of the Fall. It takes an Odyssey of travelling even to frame, never mind answer, the questions posed, to accommodate the puzzlements, simply to hope to be able to find your way back. In Moscow I attended an extraordinary packed-out concert by baritone Dmitri Hvorostovsky, in the Palace theatre in the Kremlin, singing songs of Russian nationalism and the Great Patriotic War. And I recognised it.

Everywhere I've been

I've come from somewhere else

That snatch of Russian song just now

tells me I was never there:

not even on the night

I saw the famous author come on stage

to sing the words himself

head tilted

$$
\begin{aligned}
& \text { like his photograph } \\
& \text { his nostrils flared }
\end{aligned}
$$

Not in those same words

Inside those words

That unique run of notes

It was the corncrake that I missed

the melting snow.....

Not to have been invisible 
Just that: to be here at the end to see ourselves

in those same seats we started out in when they bring the houselights up 